\title{
Settler Fragility: Four Paradoxes of Decolonizing Research ${ }^{1}$
}

\section{Fragilidade de colonizador: quatro paradoxos da pesquisa de descolonização}

\author{
Kaitlyn Watson ${ }^{2}$, Sandra Jeppesen ${ }^{3}$
}

\begin{abstract}
This dialogic autoethnography, in which the authors reflect on their experiences as settlers who have researched with Indigenous communities, maps four paradoxes settler researchers need to negotiate in decolonizing research. The term "settler fragility" signals a settler positioning of innocence in colonization, which simultaneously recenters colonial power to secure settler futures. In research, settler fragility must be confronted through four paradoxes: (1) the paradox of learning Indigenous worldviews in a profound way, but without appropriation; (2) the paradox of unsettling research by undoing colonial epistemologies in which settlers problematically aim to feel settled; (3) the paradox of reconciling research to improve relationships with Indigenous communities, which can lead to reconciling settlers with their place in colonialism, rather than with Indigenous research partners; and (4) the paradox of decolonizing research in which settler research in colonial universities is recognized as incommensurate with decolonization and yet must be undertaken to decolonize the university. Contributing a tentative set of settler research practices, this paper aims to expand dialogues about how settlers can overcome settler fragility through negotiating the four paradoxes of decolonizing research to develop authentic relationships with Indigenous communities, researchers and research partners.
\end{abstract}

Keywords: Decolonizing methodologies; Reconciliation; Systemic anti-Indigenous racism; Dialogic autoethnography; Settler research.

Resumo: Essa autoetnografia dialógica, na qual os autores refletem sobre suas experiências como colonos que pesquisaram com comunidades indígenas, mapeia quatro paradoxos que os colonizadores precisam lidar na pesquisa de descolonização. $\mathrm{O}$ termo "fragilidade do colono" sinaliza um posicionamento do colono de inocência

\footnotetext{
${ }^{1}$ This research was supported by the Lakehead University Research Chair in Transformative Media and Social Movements.

${ }^{2}$ Kaitlyn Watson holds a doctorate in Education Studies, field of Critical Policy, Equity, and Leadership Studies, from Western University in Ontario, Canada. She also completed a Master of Arts in Canadian Studies and Indigenous Studies at Trent University, as well as Bachelor of Education and Honours Bachelor of Arts and Sciences from Lakehead University. She is currently a Faculty Development Officer at Ontario Tech University and Research Coordinator with the First Nations With Schools Collective in partnership with Western University. She has published in academic and professional magazines.

${ }^{3}$ Professor in Media, Film and Communications at Lakehead University in Orillia, Canada. Co-editor, with Dr. Paola Sartoretto, of Media Activist Research Ethics: Global Approaches to Negotiating Power in Social Justice Research (2020). Jeppesen has held Research Fellowships at the ZeMKI Centre for Media, Communication and Information Research at Universität Bremen (2018), as well as the Faculty of Computer Science, Deggendorf Institute of Technology, Germany (2019); and has held the Lakehead University Research Chair in Transformative Media and Social Movements (2016-18). She is Principal Investigator and co-founder of the Media Action Research Group (2013-2019; mediaactionresearch.org). She has been lead co-organizer of the Protest Media Ecologies Symposium, Scuola Normale Superiore, Florence, Italy (2017), and of the Media Action Research Conference, Lakehead University, Canada (2016). Her monograph, Transformative Media: Intersectional Technopolitics from Indymedia to \#BlackLivesMatter is due out this year with University of British Columbia Press (2021).
} 
diante da colonização, que, simultaneamente, recentraliza o poder colonial para assegurar o futuro do colono. Na pesquisa, a fragilidade do colono deve ser confrontada por meio de quatro paradoxos: (1) o paradoxo de aprender visões de mundo indígenas de uma forma profunda, mas sem apropriação; (2) o paradoxo da pesquisa perturbadora ao desfazer as epistemologias coloniais nas quais os colonos procuram problematicamente se sentir instalados; (3) o paradoxo de reconciliar pesquisas para melhorar as relações com as comunidades indígenas, o que pode levar a reconciliar os colonos com seu lugar no colonialismo, em vez de com os parceiros indígenas de pesquisa; e (4) o paradoxo da pesquisa de descolonização, em que a pesquisa dos colonos nas universidades coloniais é reconhecida como incomensurável com a descolonização e, ainda assim, deve ser empreendida para descolonizar a universidade. Contribuindo com um conjunto provisório de práticas de pesquisa de colonos, este artigo visa expandir os diálogos sobre como os colonos podem superar a fragilidade dos colonos negociando os quatro paradoxos da pesquisa de descolonização para desenvolver relacionamentos autênticos com comunidades indígenas, pesquisadores e parceiros de pesquisa.

Palavras-chave: Metodologias de descolonização; Reconciliação; Racismo anti-indígena sistêmico; Autoetnografia dialógica; Pesquisa de colonos.

\section{Introduction}

Canada is a settler colonial nation-state established upon Indigenous ${ }^{4}$ lands (LOWMAN \& BARKER, 2015). The Truth and Reconciliation Commission of Canada's final report documents findings from its multi-year truth-telling process regarding intergenerational fallout of the residential school system and related colonial policies (TRC, 2015). For more than a century, residential schools took in over 150,000 Indigenous children with the government's objective "to eliminate Aboriginal people as distinct peoples and to assimilate them into the Canadian mainstream against their will" (TRC, 2015, p. 2). Forcibly removed from family homes, children were forbidden their languages, spirituality, and cultures. They were brutally subjected to European illnesses (MILLOY, 1999; TRC, 2015); starvation and nutritional experiments (MOSBY, 2013); sexual, physical, emotional, and spiritual abuse (TRC, 2015); and an overall lack of care (MILLOY, 1999), with many not surviving.

Having established these truths (not all of which are accepted by all settler Canadians), the report contains 94 Calls to Action, positing that "reconciliation is about establishing and maintaining a mutually respectful relationship between Aboriginal and

\footnotetext{
${ }^{4}$ We use the terms Aboriginal and Indigenous depending on context. Indigenous is an international term and is becoming the preferred term in Canada to refer to First Nations, Métis, and Inuit peoples. Aboriginal has historically been used by the Canadian government.
} 
non-Aboriginal peoples" (TRC, 2015, p. 6). Research plays a key role, "contributing to healing and transformative social change" (TRC, 2015, p. 293).

However, Māori scholar Linda Tuhiwai Smith (2012, p. 1) suggests that “"research' is probably one of the dirtiest words in the indigenous world's vocabulary". In "research through imperial eyes" (p. 58) colonial interpretations of Indigenous cultures are asserted as truths (BRANT CASTELLANO, 2004; ERMINE, 2007; SMITH, 2012), both enacting and invisibilizing domination through epistemological colonialism and exclusion (DE SOUZA SANTOS, 2014).

This is not just historical. "Research within late-modern and late-colonial conditions continues relentlessly and brings with it a new wave of exploration, discovery, exploitation and appropriation" (SMITH, 2012, p. 25). Indigenous researchers, however, have long resisted colonial research using Indigenous methods (ABSOLON \& WILLET, 2005; KOVACH, 2009; WILSON, 2008). In Canada, in 1998 the OCAP® principles established the importance of Indigenous ownership, consent, access, and possession of research processes and data (FIRST NATIONS INFORMATION GOVERNANCE CENTRE, 1998).

If colonization is a relationship negotiated partially through research, then so must decolonization be (DAVIS, 2004). The co-authors have worked on building relationships with Indigenous communities in critical decolonizing research (DENZIN \& LINCOLN, 2008; KOVACH, 2009) in which we have been asked: "Who are you and why do you care?" (CLARK, 2016, p. 46). The subjectivity of the researcher shapes intentions, legitimacy, and worldview. Thus we "situate ourselves in our writing, to start from our intentions" (p. 46).

Kaitlyn Watson is a cis-gender, female, Euro-Canadian settler born and raised in Ontario, Canada on Williams Treaty territory. She is a teacher and researcher, but perhaps most formatively, a sister, daughter, wife, and mother. Kaitlyn ${ }^{5}$ recently completed her doctorate in which she examined educator perspectives on reconciliation. Most broadly, she is interested in exploring Indigenous/settler relationships in the past and present.

Sandra Jeppesen is a cis-female white settler, born in Vancouver in Coast Salish Territory, with ancestors in Denmark and Ireland, places she has lived for some time.

\footnotetext{
${ }^{5}$ We transgress the expectation that scholars should be referred to by surname to be seen as objective and refer to ourselves by first names to challenge the erasure of women's subjectivities from research.
} 
For 25 years she has engaged in multi-issue social movements through intersectional anti-oppression practices, including decolonization. She sits on the President's Council on Truth and Reconciliation and has partnered in a storytelling circle research project with a local Indigenous women's centre.

Through dialogic autoethnography, we elucidate four paradoxes in decolonization research: (1) the paradox of learning Indigenous worldviews without appropriation; (2) the paradox of unsettling research by undoing colonial epistemologies without settlers feeling settled; (3) the paradox of settlers reconciling research to improve relationships with Indigenous communities without recentering settlers; and (4) the paradox that decolonizing settler research is incommensurate with decolonization yet must be undertaken to decolonize universities. To negotiate these paradoxes, settlers must confront settler fragility.

The term "settler fragility", building on non-Indigenous ${ }^{6}$ scholar Robin DiAngelo's work on white fragility (2018), is defined by Dina Gilio-Whitaker (2018b, np), Colville Confederated Tribes and lecturer in American Indian Studies, as "the inability to talk about unearned [settler] privilege — in this case, the privilege of living on lands that were taken in the name of democracy through profound violence and injustice". She points out that in North America, "all of today's settlers and immigrants are in one way or another beneficiaries of genocide and land theft, even if they are simultaneously themselves victims of other forms of discrimination" (2018a, np). The positioning of oneself as oppressed on one axis of identity (by anti-Black racism, sexism, heterosexism, cis-sexism, and so on) and therefore incapable of benefitting from privilege on another axis enacts and invisibilizes settler privilege. Settler fragility can lead settlers to ignore the persistence of settler colonialism, deny their settler privilege, and prevent decolonization work to dismantle its structures.

Everyday practices of settler fragility, based on settlers" "fragile self-regard" (JUSTICE, 2017), include: denial of systemic anti-Indigenous racism; anti-Indigenous micro-aggressions; stereotyping Indigenous peoples; and professing innocence when called out on anti-Indigenous racism (FELLOWS \& RAZACK, 1998; TUCK \& YANG, 2012). As Gilio-Whitaker (2018b, np) notes, "settler privilege is systemic, so just denying that one doesn't possess it doesn't mean one isn't complicit in it."

\footnotetext{
${ }^{6}$ We use the terms non-Indigenous and settler interchangeably.
} 
In the context of research, settler fragility appears as: fear of negative interactions in Indigenous communities; not acknowledging Indigenous research leadership; not following $\mathrm{OCAP}{ }^{\circledR}$ principles or Indigenous protocols; not taking the time to develop research relationships; colonial university practices; not citing Indigenous scholarship; not supporting Indigenous students and scholars; and so on. We therefore argue that settler fragility must be confronted through negotiating four key paradoxes in decolonizing research if settlers are to successfully partner in research with Indigenous communities. We argue this provisionally because negotiating these four paradoxes does not produce answers, but raises further questions, some of which we map below.

\section{Theoretical Framework}

Here we provide basic definitions for concepts corresponding to the four paradoxes.

\subsection{Appropriation}

Appropriation of Indigenous cultures is defined as follows:

using intellectual property, traditional knowledge, cultural expressions, or artifacts from someone's culture without permission [which] ... is most likely to be harmful when the source culture is a group that has been oppressed or exploited in other ways ... or when the object of appropriation is particularly sensitive or sacred (ANTOINE et al., 2018, p. 38).

Shand (2000), a Pākehā or non-Māori New Zealander, describes three types of appropriation by settlers: (a) commercial exploitation, using cultural knowledge and artifacts for economic gain; (b) "modernist 'affinity" (p. 4), appreciating Indigenous art, maintaining elements but disrespecting cultural meanings; and (c) "post-modern quotation" (p. 5), borrowing Indigenous art iconography, ignoring its cultural context.

Settler ethnographer Celia Haig-Brown (2010, p. 925) differentiates between appropriation and "deep learning," favouring the latter. She poses an unresolved question: "when and how does learning a secondary discourse [deep learning] become 
cultural theft?" (p. 929). Crucial considerations include: who is sharing the knowledge and who is listening; what is done with the knowledge; citing sources of knowledge; following protocols; and responsibility for sharing knowledge one receives (HAIG-BROWN, 2010). With deep learning, we may better understand Indigenous cultures without appropriation. However, there are no guarantees; what constitutes cultural appropriation is at times ambiguous (HAIG-BROWN, 2010; ANTOINE et al., 2018).

\subsection{Unsettling}

Unsettling research means undoing colonial research practices by decentering settlers, who must confront and cede the benefits of colonialism (HELD, 2019). Moving past fragility or discomfort, "settlers cannot just theorize about decolonizing and liberatory struggle: we must experience it, beginning with ourselves as individuals, and then as morally and ethically responsible socio-political actors" (REGAN, 2010, p. 23-24). According to settler scholar Craig Fortier (2017, p. 23), unsettling research involves three key practices: first, "identification and belonging" (i.e., the ways people self-identify and the spaces to which they belong); second, "accountability and consent" (i.e., accountability to research relationships and ongoing consent); and third, "responsibility and [avoiding] appropriation" (i.e., being responsible to Indigenous research partners through deep learning without appropriation). Unsettling research methods do not protect settler fragility, but are dynamic negotiations towards undoing colonialism which may and must leave the settler researcher unsettled.

\subsection{Reconciliation}

Reconciliation refers to "peaceful coexistence of two or more parties" (WOOLFORD, 2004, p. 431) or the conciliation of a fraught relationship (TRC, 2015).

Reconciliation in Canada is controversial. Cree scholar Kiera Ladner (2018, p. 248) argues that Canada needs to "reconcile itself with the great historical myths and lies that form the legal and political bedrock of this nation". Roland Chrisjohn, from the Oneida nation, and Tanya Wasacase, Cree from Saskatchewan (2009, p. 199), note that 
reconciliation "insinuate[s] a revised and bogus history ... imply[ing] that, once upon a time, Indigenous peoples and settlers lived in peace and harmony". The TRC (2015, p. 6) itself acknowledges that the relationship has never been "conciliatory", therefore offering no positive relationship to return to. For non-Indigenous scholars Ravi de Costa and Tom Clark (2011), government statements of reconciliation have served to normalize colonial injustice. This has enabled the government to control the process, outcomes, and narratives of reconciliation, avoiding meaningful actions towards restitution (WATSON, 2020). In the research context, Indigenous and Western research methods are not reconcilable (HELD, 2019). Moreover, Unangax ^scholar Eve Tuck and settler scholar Wayne Yang (2012) argue that reconciliation is insufficient to achieve decolonization.

\subsection{Decolonization}

Decolonization supersedes reconciliation to dismantle the base structures that maintain colonial hegemony. Decolonizing research "involves a paradigm shift from a culture of denial to the making of space for Indigenous political philosophies and knowledge systems as they resurge, thereby shifting cultural perceptions of power relations" (REGAN, 2010, p. 189). It rejects "the privileging of dominant Euro-centred cultural values and beliefs in education, scholarship, knowledge production, the legitimization of intellectual capital, and the networks and systems of power" (STYRES, 2017, p. 19). Confronting power structures, decolonization explicitly also calls for repatriation of land. Arguing that decolonization is not a metaphor ${ }^{7}$, alluding to the race to innocence (FELLOWS \& RAZACK, 1998), Tuck and Yang (2012, p. 3) map six settler moves to innocence that "attempt to reconcile settler guilt" and consolidate "settler futurity".

First, "settler nativism" occurs when "settlers locate or invent a long-lost [Indigenous] ancestor" (p. 10), often a grandmother, rendering the settler innocent through proximity. However, if this grandmother exists, there is no innocence as she is likely the offspring of "rape and sexual violence" (p. 11). Moreover, settler nativism transgresses Indigenous nations' determinations of Indigenous identity (p. 13).

\footnotetext{
${ }^{7}$ Please, see Garba \& Sorentino (2020) for a critical analysis of Tuck \& Yang's "Decolonization is not a metaphor".
} 
Second, in "settler adoption fantasies" (p. 13), settlers adopt Indigenous lifestyle signifiers, demanding Indigenous peoples allow themselves to be colonized by this benevolent settler, "a fantasy that is invested in a settler futurity and dependent on the foreclosure of an Indigenous futurity" (p. 14). Film narratives supporting the adoption fantasy include Dances With Wolves, The Last of the Mohicans, and Avatar.

Third, "colonial equivocation" (p. 17) posits an equivalency between racialized and colonized groups, eliding the specificity of Indigenous peoples. This is sometimes used "in coalition politics among people of color" (p. 17), denying that the racialized non-Indigenous speaker is a settler (p. 17), also noted by Dhamoon's (2015) call to decolonize anti-racism movements.

Fourth, "free your mind and the rest will follow" can obfuscate the need for "relinquishing stolen land" (TUCK \& YANG, 2012, p. 19). Building upon Fanon and Freire's arguments for critical thought and action in everyday life, Tuck and Yang (2012, p. 21) argue decolonization must move beyond the intellectual; the rest does not naturally follow.

Fifth, the trope of "a(s)t(e)risk peoples" (p. 22) renders Indigenous peoples visible in settler pedagogies only as at risk (vulnerable populations) and in scholarship only as asterisks (requiring footnotes). This erases and then conceals the erasure of Indigenous peoples, "a body count that does not account for Indigenous politics, educational concerns, and epistemologies" (p. 23), silencing them as always-already voiceless or victims.

Finally, sixth is the trope of the Occupy movement, "another settler re-occupation on stolen land" (p. 23). Occupy's use of images equating wealth to land ownership erases both Indigenous non-monetary relationships to land, and the reduction of Indigenous lands on reserves to less than 3\% of the United States (p. 25).

These moves to innocence turn decolonization into an empty metaphor, however decolonizing research depends on decolonization's very material form.

\section{Methodology: Dialogic Autoethnography}

Dialogic autoethnography is a methodology for engaged reflections. Autoethnography articulates personal narratives that deepen theoretical reflections on 
research (BRE, 2007). For settler scholars David Butz and Kathryn Besio (2009, p. 1660), this methodology proceeds from the self "to understand or represent some worldly phenomenon that exceeds the self". Through self-reflection, researchers confront how they are "involved in the active construction of social reality and sociological knowledge" (BRE, 2007, p. 229). Self-reflexive narratives can call into question research power dynamics and processes that construct social realities and knowledge based on colonial epistemologies. Dialogic autoethnography, by extension, produces self-reflexive dialogues comparing and contrasting empirical research practices among researchers and across disciplines.

Indigenous scholars have used autoethnography to center Indigenous voices. Māori scholar Paul Whitinui (2014, p. 456) characterizes it "as a culturally informed research practice that is not only explicit to Māori ways of knowing but can be readily validated and legitimated as an authentic 'Native' method of inquiry". Aligned with this, Cree scholar Onawa McIvor (2010, p. 137) engages a "blend of autoethnography with Indigenous methodologies". Indigenous approaches to autoethnography see storytelling as a relationship (HOUSTON, 2007; ABSOLON \& WILLET, 2005). As Sto:lo researcher and educator Jo-Ann Archibald (2008, p. 127) explains,

In the Coast Salish oral tradition of the author and of many other First Nations cultures, when life-experience stories are used for educational purposes, the listener/reader is expected to make meaning with the story given.

Autoethnographic narratives are inherently dialogical, interpellating the audience into constructing realities.

While storytelling is culturally valued, autoethnography is often undervalued in the academy. For racialized, Indigenous and/or feminist scholars engaging in community-led ethnographies, "a value free assessment of the 'quality' and 'excellence' of their scholarship is necessarily affected by the kind of work they do, and especially the kinds of communities it serves" (COTERA, 2010, p. 329). The "value-free assessments' of the neoliberal university system judge subjugated knowledges produced by intersectional, anti-racist, feminist and/or Indigenous autoethnographers as inadequately rigorous, resulting in these scholars being granted degrees, tenure-track positions, tenure and promotion, high-ranking administrative positions, research 
funding, and so on less often than peers from dominant groups (HENRY et al., 2017). However, autoethnography is a rigorous methodology; it can produce empirical, theoretical, valuable advances in interdisciplinary scholarship. Moreover, through dialogic autoethnography, "the scholar is not left on her own with her [research] diaries and thoughts, but rather discusses the common and different experiences of the research practice with another scholar" (YURCHUK \& VORONOVA, 2020, p. 252). This provides for expanded mutual learning, at least partially addressing the critique of autoethnography that one person's research experience cannot stand in for an entire field.

We use dialogic autoethnography to interrogate paradoxes within our research and pedagogical activities, in alignment with decolonizing autoethnography, but without appropriating Indigenous autoethnography. The narratives presented here derive from discussions and independent and collaborative writing over the course of two years, reflecting on our own and each other's experiences.

There seems to be a paradox here too. How do we decenter settlers, while also producing knowledge from the standpoint of, and for the further use of, critical decolonizing settler researchers? How do we ensure this dialogue engages with Indigenous communities? Can we characterize our knowledge as partially subjugated? We are women researchers in the university where this topic and methodology is not highly valued, but at the same time, in relation to colonial power structures we occupy positions of relative power, locating us in an intersectional paradox. How do we negotiate these competing subjectivities and objectives? This question is at the center of the four paradoxes explored below.

\section{The Four Paradoxes of Decolonizing Research from Settler Perspectives}

Through this series of autoethnographic dialogues, we critically analyze four paradoxes in decolonizing research. We present them here as linear personal narratives although they did not happen in this way and were much more overlapping and circular.

\subsection{The Paradox of Appropriation}


Wanting to deeply understand Indigenous knowledges and cultures without appropriating them is often the first paradox a settler student or researcher will encounter; however deep learning may inadvertently lead to appropriation.

In Canada there is a long-standing public debate on appropriation to which the contentious publication of books by settler authors on the cases of Loretta Saunders and Coulten Boushie has contributed. First, in 2018 a non-Indigenous writer, Shannon Webb-Campbell, published a book of poetry on the murder of Inuk scholar Loretta Saunders, entitled Who Took My Sister?. Saunders is among the almost 2,000 missing and murdered Indigenous women, girls, and two-spirit people in Canada (NATIONAL INQUIRY, 2019), a subject she herself was researching. The poetry included graphic descriptions of Saunders' physical body after death, considered by her family to be culturally inappropriate and disrespectful, as was the fact that Webb-Campbell had not contacted the family or received permission. The book was later retracted and funds from past sales donated to the Loretta Saunders scholarship fund (MCKENZIE-SUTTER, 2018).

Second, in 2018, Coulten Boushie, a Cree man from Red Pheasant First Nation, was shot and killed by Gerald Stanley, a white farmer who was controversially acquitted of both murder and manslaughter. A book titled Canadian Justice, Indigenous Injustice: The Gerald Stanley and Coulten Boushie Case, produced by settler Canadian law scholar, Kent Roach, was published in 2019 without consulting the family. The critiques were numerous. In a CBC article by Ntawnis Piapot, Nehiyaw Iskwew from Piapot Cree Nation, Roach said he engaged solely with the public and legal record on the case to avoid the rigorous process of Research Ethics approval for work with Indigenous peoples, as he wanted the book published on the one-year anniversary of the verdict. Nikita Longman, a Saulteaux writer from the George Gordon First Nation, said:

\footnotetext{
'This isn't the first time — and it won't be the last time — that settlers, particularly white men, control a narrative of our history,' she said. 'I can't help but feel that the way that we process pain and the way that we process our histories are very different than the way that settlers and academics and scholars and even lawyers would process it' (LONGMAN as cited in PIAPOT, 2019, np).
}

If writing about Indigenous peoples, settlers must take care to get their consent and approval; not to do so is appropriation. These two cases form the partial context of 
national events and debates concurrent to our dialogues.

Kaitlyn: "I had very little prior knowledge about contemporary Indigenous peoples from elementary and secondary school, and in my personal life. Growing up there were only ahistoric and pan-Indigenous artifacts presented to me in school with a generalized focus on teepees and totem poles - which certainly involved appropriation (ANTOINE et al. 2018). I entered university with the paradoxical notion that Indigenous peoples were extinct despite the fact that we had family friends who identified as Indigenous. This contradictory notion and my realization that it was problematic led me to new learning spaces and further complications.

While I have always been invited into the Indigenous learning spaces I find myself in, and my settler positionality is known, I continue to feel a tension related to my positionality: as a beneficiary of colonization, how do I engage with learning from Indigenous knowledges? What can I or should I do with the learning I glean? How can I respectfully incorporate these new understandings of land, relationships, and community into my own worldview, without appropriating Indigenous knowledges?

I entered my doctoral program with a plan to investigate my experiences as a settler Canadian learning about Anishinaabe culture in an Anishinaabe learning institution, through autoethnography. I had attended this school through a summer immersion program I joined while completing my master's degree and I had built relationships that grew beyond the immersion program. I hoped this research would inform how Indigenous perspectives could be included in Ontario classrooms to support meaningful learning for all students and teachers. As my supervisor and I discussed my plans, and, informed by his positionality as Anishinaabe, we questioned the practicality of the data collection and my positionality as a settler seeking access to this Indigenous institution where I would be gathering knowledge from another culture. We also had concerns that this research would contribute to the homogenization of Indigenous knowledges by advocating for the integration of Anishinaabe principles into an education system with a very diverse Indigenous population. We decided to move my work to a new topic and I continue to be grateful for my supervisor's insight and expertise. Following this important learning I hold unresolved questions about including Indigenous perspectives in research, and, perhaps more delicately, if and how I can include these values and beliefs in my daily life?" 
Sandra: "As far back as when I was a graduate student activist, my research and teaching have been grounded in anarchist intersectional anti-oppression frameworks, with decolonization as a key axis of structural oppression, along with race, class, gender, sexuality, disability, and so on. I have learned that Indigenous rights, however, are not to be conflated with other social justice claims because colonial systems of land and cultural appropriation are unique to Indigenous groups (CLARK, 2016; TUCK \& YANG, 2012). This is not meant to create a competition among axes of oppression (DHAMOON, 2015; FELLOWS \& RAZACK, 1998). My encounter with settler fragility circles in my mind: I don't want to teach or research through my intersectional worldview, risking colonization by appropriation, nor do I want to neglect Indigenous knowledges, risking colonization by silencing. This paradox points to a question regarding the limits of settler knowledge.

I first encountered this paradox as a graduate student in Germany teaching 'Canadian Culture'. I introduced an anthology by Indigenous writers, artists, theorists, and so on. It was difficult for the students to understand these Indigenous narratives, having grown up in Germany with romanticized stereotypes, further perpetuated by a museum exhibit on 'Sitting Bull' that we visited during the course. Students told me they wanted the Canadian version of the 'trail of tears' (narrated by settlers). I problematized student assumptions, but this unfortunately had a silencing effect. We had reached the limits of our knowledge (this was pre-internet). When this happens, one option is for settlers to bring in Indigenous Elders to share teachings, but we also need to do our own homework and learning.

The paradox of appropriation means I step back from the position of expert, and teach with partial, fragmentary knowledge. I integrate Indigenous materials, foreground discussions of appropriation, and use Indigenous scholarly sources, following Western citation practices. However, in research, participant names are often anonymized to protect identities, privileging scholars (cited) over research participants and community members (not cited) (JEPPESEN, 2020). Instead, attribution must follow Indigenous dictates and practices established through dialogue. This is unsettling - and it should be."

\subsection{The Paradox of Unsettling Research}


Unsettling the practices of settler-centered research, destabilizing the relative security of our intersectional, marginalized and often precarious, but, nonetheless, settler positions in the colonial university, will be uncomfortable. We pose this paradox as a question: Does recognizing that this is unsettling contradictorily serve to make us feel more settled?

Kaitlyn: "Growing up, stories shared with me about Canada in and outside of school perpetuated a narrative of Canada as a tolerant, peaceful, multicultural mosaic. Realizing the history and present of genocide in Canada (e.g., residential schools [MILLOY, 1999; TRC, 2015], the epidemic of missing and murdered Indigenous women and girls [NATIONAL INQUIRY, 2019], and more) was and continues to be jarring. When I learned these truths, I immediately felt guilty this was/is happening and my government was/is responsible, but I was unsure what to do with these feelings.

Eventually, through academic and community-based learning, I came to a cognitive dissonance regarding the purpose of education. My interest in what I most broadly refer to as Indigenous education essentially arose from my discomfort that the education system I was indoctrinated in, and was being trained to contribute to as a formal teacher, holds the power to allow settlers to feel both settled about our history (e.g., boast of the fur trade in Canada as relationship building) and unsettled (e.g., express remorse for the residential school system) in ways that centre settler dominance.

Moving forward to my doctoral research, I am reminded of the tensions between settler fragility and guilt. During an interview with an older Indigenous man, he shared with me, in one of the longest interviews I had, about his family, his work, and the communities he belongs to. I too shared about my family, my education, and my research plans. At one point in the interview, he commented that I had shared quite a bit about myself. I took this as a positive sign because my intention was to have conversations with the people who agreed to be in my study as a mean to disrupt traditional interviewing practices. We, too, had a discussion about my settler positionality and how I came to the research project. In this dialogue, he reminded me that Indigenous peoples do not want guilt. Since that conversation I have more deeply reflected on my intentions for research with Indigenous peoples and I'm left with a few questions. By doing research that challenges, critiques, or intervenes in colonialism, am 
I settled by feeling good about feeling bad (AHMED, 2004)? Related to Tuck and Yang's (2012, p. 9) "settler moves to innocence," I wonder if settler interest in decolonizing research is predicated on an unconscious desire to maintain "settler futurity"? Do I engage with this field of study to justify that I belong? Is there a way for settler researchers to engage in research that does not benefit their existence as settlers on Indigenous lands?"

Sandra: "Unlike Kaitlyn, I knew very little about Indigenous cultures from community experience; I was more informed by book learning as well as activist spaces that tended to include some Indigenous activists and politics. I decided to reach out to a local Indigenous women's centre to see if we might do a project together, connecting through gender empowerment, while understanding there are differences in gender oppression in the contexts of being Indigenous or being a settler. I attended full moon ceremonies, sunrise ceremonies, literary festivals, a teepee raising, and other cultural events. Settler fragility meant that although I was curious and wanted to initiate conversations, I erred on the side of quiet. When I spoke, I kept comments short, not wanting to recenter settler voices in Indigenous spaces. While circumspect, this approach reduced my risk and vulnerability, preventing Indigenous people from getting to know me. There is a fine line between knowing when to listen and when to speak, as Kaitlyn noted above. Walking this line is unsettling for settler researchers, who are good at lecturing and perhaps unaccustomed to listening. We know too much to know where to start a conversation. We know enough to ask, is any of our knowledge correct?

I felt unsettled about approaching the women's centre, not wanting to ask them to take time to work on a project with me when they were clearly busy with many other projects to support community women and families. After one meeting that had seemed fruitful, I did not hear back and was unsure about the next steps. When the funding needed to be used or lost, I wrote a heartfelt e-mail articulating my motivations, interest, and openness to feedback and change. I made it very personal and it seemed to connect us better. Following local Indigenous protocol, I brought tobacco to the next meeting, as a sign of respect and a commitment to doing things in a good way. At that meeting I received teachings on tobacco and on the importance of grandmothers, beautiful stories that grounded my entry into the project. I proposed we work on a media or cultural 
project, offering the funds to support it. ${ }^{8}$ After one hour, one of the Elders said she still did not know what I was asking for. I said I wasn't asking for anything; I did not presume to know what would be good for their centre, but rather - was there a project they wanted to work on that I could support? My only objective was to positively impact women's lives. They were surprised. They said that they had never been offered a blank slate like that before. We decided on a storytelling research project supported by a grandmothers' circle, which we ran successfully for a year and a half.

To develop the Storytelling Circle, they invited the community to an open conversation to see if there was interest and, if so, what it might look like. This was facilitated by one of the Elders I had met with. I introduced myself, my research and activist background, and then took a back seat, listening and learning. This felt similar to an anarchist participatory decision-making circle, but I do not want to inscribe my settler political framework on the Indigenous talking circle. I felt comfortable due to this similarity, but also unsettled knowing I could not understand the cultural context and subtexts that made it very different. In fact, I often felt unsettled.

The unsettled outsider is a paradoxical feeling in relation to my experience of acceptance. They didn't expect anything from me. I could talk, not talk, laugh, not laugh, eat, not eat, nobody cared or said anything one way or the other when I was there. They invited me to join them in making art and to share my story. They talked about hard experiences: losing children to Children's Aid Society (CAS), alcohol abuse, partner or parental violence, parents in residential schools, or being torn from a grandmother's arms in the Sixties Scoop. The participants felt accepted, spoke freely about their experiences, learned about their culture, and, they said, experienced a sense of belonging and healing. Some of their stories resonated with my own. My mother experienced CAS home removal as a child and lived in abusive foster homes. Alcohol is a multi-generational issue in my family. Sharing stories of my own allowed for deeper connections across cultural differences. I could speak about what I have been through in ways that I would not among settler friends. But I also wondered, was I doing harm by being there in ways that I could not see?

I felt settled but unsettled, inside but outside. My place in the world had shifted, but not changed. I still feel unsettled. I am still a settler. Unsettling research changes

\footnotetext{
${ }^{8}$ At the time, Sandra was the Lakehead University Research Chair in Transformative Media and Social Movements.
} 
you but it does not change who you are. Unsettling research changes research too, but it does not change settler colonial university research structures."

\subsection{The Paradox of Reconciling Research}

Universities in Canada are focused on reconciliation through the TRC's Calls to Action (TRC, 2015). The TRC process involved a truth-telling research phase followed by the development of Calls to Action on reconciliation. The commission held open truth-telling forums in communities, with the resultant recordings and other materials archived, for now, at the National Centre for Truth and Reconciliation (NCTR) in Winnipeg, Manitoba. Now Indigenous and settler researchers are called on to commit to research for truth and reconciliation.

Reconciling research as an initiative of the Canadian state produces several paradoxes. First, Indigenous critiques of reconciliation may contribute to feelings of settler fragility. Should we be circumspect about the critiques and not engage in reconciliation research? Or should we inform ourselves of the critiques as a pathway to reconciliation, negotiating its shortcomings and attempting to move beyond them?

Second, how is research initiated? On one hand, it might be important to take initiative to research with Indigenous communities, offering to put energy, capacity, and funds from the colonial institution toward transformative research with Indigenous communities. However, this might be perceived as do the actual work of re-colonizing via a settler adoption fantasy, a move to innocence in which the researcher adopts themself out to the community through reconciliation research intended to benefit the Indigenous community but which in actuality only benefits the settler researcher by both establishing and invisibilizing the difference between the two. Thus, on the other hand, it seems important to wait to be invited into the community to research, deferring to Indigenous leadership in community-led research. However, this might also be perceived as a reticence to take responsibility for reconciliation with Indigenous communities, instead resting in settler fragility through the move to innocence, "free your mind and the rest will follow" (TUCK \& YANG, 2012). In this move, we think, we read, we wait for an invitation, but resting safely in our settler fragility, we do not take action. How do we negotiate this paradox to start reconciliation research projects in 
a good and ethical way?

Third, we are not in favour of a stampede of settler academics, Calls to Action and funding applications in hand, rushing into Indigenous communities to generate research that makes a show of reconciliation. Non-Indigenous scholar Sirma Bilge (2013) refers to this as "ornamental diversity", a superficial approach of ticking boxes confirming engagement in diversity, reconciliation, or other anti-racist initiatives, but nonetheless continuing to do things the same old racist, colonial way.

These three paradoxes spawn a host of questions. If research expertise or funding is needed by a community, how do anti-colonial settler researchers find out, or conversely, how do Indigenous researchers or communities find us? What might initiatives look like from the perspective of a particular Indigenous community? How can reconciliation research be offered in ways that are not patronizing but build relationships of respect and equality? How can we move past settler fragility to participate in reconciliation research that makes sense for Indigenous communities?

Kaitlyn: "Despite the many critiques of reconciliation (CHRISJOHN \& WASACASE, 2009; TUCK \& YANG, 2012), for myself, as a settler on Turtle Island, reconciliation offers a useful framework to help me make sense of my relationship with Indigenous peoples. I understand reconciliation to involve a coming together and, in the Canadian context, this is a problematic notion when one considers the question, what are we bringing together, and who benefits?

The four Rs of Indigenous education, as articulated by Cree scholar Verna Kirkness and non-Indigenous scholar Ray Barnhardt (1991), include respect, relevance, reciprocity, and responsibility. I assert that they also provide a valuable framework for reconciling research. First, the tenet of respect requires that Indigenous ways of knowing and being are respected and valued for what they are. In a research context, I understand that this means valuing what Indigenous participants bring in the form of knowledge, values, and approaches which might contradict the institutional or Eurocentric way of conducting research. For my doctoral research, I embraced this tenet by bringing together methodological approaches (i.e., narrative inquiry and decolonizing methodologies) as an attempt to respect the Indigenous participants who I hoped would agree to participate in my study. While there were many methodological options I could have considered, I felt the weight of colonization on my selection of 
methodology. Choosing an 'Indigenous methodology' would be appropriation and what I consider to be a form of recolonization, however I also wanted to find an approach that respected Indigenous peoples involved with the research.

Second, the tenet of relevance described by Kirkness and Barnhardt (1991) moves beyond respect for Indigenous ways of knowing and being to insist that institutions are relevant to Indigenous peoples' lives. For research, this requires that settlers ensure their research aligns with the needs of the community within which it is situated. There are aligned mainstream methodologies (e.g., participatory action research) and other research strategies that can shore up research relevance to the community (e.g., validation of data, collaborative data analysis, sharing results directly with the community, and embracing $\mathrm{OCAP}{ }^{\circledR}$ principles). In my doctoral research, I investigated a topic (i.e., reconciliation) which has relevance for both Indigenous and non-Indigenous peoples (TRC, 2015). However, while I recruited from a broad cohort of people involved with the event my study was based on, which included both Indigenous and non-Indigenous peoples, there was a stark disparity between the number of Indigenous and non-Indigenous participants. This leaves me wondering if the topic of my dissertation was truly relevant to Indigenous peoples (or at least for those involved with the event) and if my findings represent a colonial perspective of reconciliation based on my positionality and that of most of the participants. More broadly, if research is not relevant to the Indigenous communities it involves, for whom is reconciliation taking place?

Third, the principle of reciprocity in higher learning represents a dialogical teaching and learning relationship between professoriate and students which might include educators branching out beyond the university (e.g., offering courses in Indigenous communities). Kirkness and Barnhardt (1991) provide this reminder: those who do this type of work must be humble so as to avoid bringing their academic preoccupations with them. Reciprocal research too involves a back and forth between researcher and participant(s) which might require the researcher to move outside of Western structures, physically and intellectually. My doctoral research involved some reciprocity given that the organizers had expressed interest in learning more about the outcomes of the event, however I did not have a specific Indigenous community partner who I could check in with or seek approval from. I further cultivated reciprocal research 
relationships by having conversations with participants, instead of extracting information through one-direction interviews.

The fourth and final $\mathrm{R}$ articulated by Kirkness and Barnhardt (1991, p. 15) is responsibility in which they call on Indigenous peoples to 'exercise responsibility over their own lives'. In a research context, the concept of responsibility expands in many directions and, in my case as a settler, I consider my responsibilities. Taking responsibility means I must relinquish much of what I know or have been taught to value so that I do not perpetuate colonial perspectives. Being responsible does not mean I move into spaces and attempt to identify and fix problems that are not my own. Instead, being responsible requires that I carefully consider what is appropriate research for me to participate in and recognize what the limits are."

Sandra: "We need to find ways to be responsible and accountable without taking responsibility for others. Some settlers distance themselves from the responsibility of reconciliation, because they feel they were not personally responsible for what they see as historical wrongs. Settler fragility entails an inability to face the ongoing legacies of colonialism, rooted in a short-term worldview focused on immediacy that causes us to abdicate responsibility for past, present, and future impacts. However, I argue that responsibility for reconciliation needs to be ongoing and intergenerational because the effects and impacts of colonization are like that. Research impacts come from the past, exist today, and are moving into future generations. To me, it is the intergenerational space in which reconciliation must be negotiated and the framework in which reconciling research must engage. The Storytelling Circle was intergenerational, consistent with Indigenous values, including grandmothers, mothers, and sometimes children; men also participated in different ways, as families are valued.

I engage in reconciliation research because, like Kaitlyn and other settler researchers, I feel responsible for building improved relationships with Indigenous communities towards better futures. Because of the Indigenous scholar critiques articulated above, and my anarchist critiques of the structure of settler nation-states, I see reconciliation as a process aimed toward decolonization, rather than an end in itself.

Who benefits in reconciling research is a question Kaitlyn invited me to reflect on. In the Storytelling Circle, Indigenous participants benefited in ways that I did not, e.g., having an open, long-term supportive community space that strengthens cultural 
knowledge, and belonging that they can always return to. Conversely, I benefitted in ways that they did not, e.g., having my research valued for promotion and merit. We have benefitted mutually from participation in making art and telling stories, producing friendships that extend into the broader community. Are these equal although different kinds of benefits? Assessing this can be unsettling, and should, perhaps, remain so. It is neither a scorecard nor a score that can be settled.

Avoiding quantitatively assessing impacts is in opposition to colonial university research scorecards that quantify research expectations and outcomes. Resisting this imperative is political and it can also be unsettling. The granting body that funded this project expects scholarly journal article publications and as yet I have produced none. The research outcomes do not belong to me because, using action research, they happened directly through participation in the Storytelling Circle. But by not producing scholarly outputs, am I doing a disservice to the women's centre, invisibilizing them somehow? I have not pursued further research, nor have they approached me to - is it my responsibility to take the next step?

Settler fragility for some settlers means that government apologies and inquiries are the end of the story, securing the issues in the past where they no longer cause harm. Settler fragility, moreover, expects the government to take care of things. But I see a role for all people, at the grassroots and beyond, to participate in reconciliation and decolonization. Critiquing settler nation-state structures, what our leaders say and do is inadequate - it sometimes feels like they say one thing (apology) and do the opposite (continue colonial policies). As members of civil society, all settlers can and should take action and responsibility for reconciliation.

Reconciliation is enacted through everyday actions across cultural lines as the lines between research and everyday life also blur. The limits of reconciliation however come into sharp focus. Is this critical dialogical autoethnography supporting decolonization? Or are we, as settlers, reconciling ourselves with recolonization?"

\subsection{The Paradox of Decolonizing Research}

Decolonization surpasses reconciliation. Settler moves to innocence in "decolonization as metaphor" rely on the recolonization of terms settlers simultaneously 
inappropriately appropriate and want to appear to be reconciling. This is due to an "ethic of incommensurability" that

guides moves that unsettle innocence, stands in contrast to aims of reconciliation, which motivate settler moves to innocence. Reconciliation is about rescuing settler normalcy, about rescuing a settler future (TUCK \& YANG, 2012, p. 35).

Decolonization is unconcerned with settler futurity. In decolonization, settler researchers must confront the colonial demands and structures of the neoliberal university. These include: Eurocentric research ethics protocols; funding eligibility, expectations and requirements; limited honoraria for research participants; metrics for quantitative research outputs; authorship practices; and so on. These structures do not easily admit Indigenous knowledges, methods, values, relationships, or epistemologies; they produce a border that must be transgressed and dismantled. Settler researchers supporting decolonization can align themselves with these objectives.

Decolonization would therefore not just appreciate, unsettle, or reconcile but completely dismantle colonial research structures through supporting the restitution of Indigenous cultures, knowledge production, land, and self-governance structures. As such, decolonizing research destabilizes settler futurity. What is our role in decolonizing research is no longer the question. The question — and the paradox — in decolonizing research is how settlers can dismantle the colonial authority of the very settler spaces that legitimate us to pose this question.

Kaitlyn: "As a settler-Canadian who has taken up Indigenous-settler relations as my field of study, I often feel lost, confused, concerned, and apprehensive about my role in research - is this my settler fragility? When I first saw Smith's (2012) "Decolonizing Methodologies" I was excited because I thought it might answer my questions about the role I can play in decolonizing education and research. However, after reading, discussing, and attempting to actualize efforts of decolonization, I am left wondering if they are truly decolonizing and, in the context of settler colonialism, can they ever be truly decolonizing? This is the paradox.

My doctoral research intended to engage decolonizing research practices. I drew on the Western/mainstream methodology of narrative inquiry (CHASE, 2011; CONNELLY \& CLANDININ, 1990; RIESSMAN, 2007) alongside decolonizing 
methodologies (KOVACH, 2009; SMITH, 2012) in an attempt to confront and resist the colonizing potential of research in Indigenous contexts as described above. While narrative inquiry holds promise for research with Indigenous communities (KOVACH, 2009), I felt that on its own, it did not hold the epistemological, ontological, or axiological assumptions aligned with my decolonizing approach to research.

Plains Cree and Saulteaux scholar Margaret Kovach (2009) explains that decolonizing methodologies are aligned with a critical theoretical orientation, which I believe invites settlers to engage. Decolonizing research calls for the researcher to self-reflexively interrupt cognitive imperialism (BATTISTE, 1986) and commit oneself to social action (KOVACH, 2009) to disrupt settler colonialism. However, my research process was rooted in Eurocentric values and expectations. I was required to follow institutional ethics guidelines that prevented me from communicating with my participants about the final copy of my dissertation once my ethics application was closed. My dissertation opened and closed with my positionality, something that felt natural to me, but was pointed out by some to be unconventional. And despite all of my intentions, it did not address the material needs of Indigenous peoples. How can settler research truly decolonize colonial spaces?"

Sandra: "As the Storytelling Circle was wrapping up, participants gave a research presentation during Research and Innovation (R\&I) Week at Lakehead University, wearing ribbon skirts they had made during the project. The women opened R\&I Week with a ceremony, smudging, singing, and drumming; together we talked about the project in a presentation; and the artwork produced was professionally framed and exhibited in the campus commons for the week. The opening ceremony was featured in the local newspaper, with pictures of the women singing and drumming. They were very proud of their accomplishments and being invited into the university. It had the effect of decolonizing the university space at least temporarily, with lasting impacts. Some said they could not have imagined this happening in their lifetime.

The final night was a big party at the centre, somewhat to my surprise, as I had prepared for a wrap-up and talking circle. This was typical. Sometimes I did not know what was happening until it happened and that was fine. In the talking circle, people were reticent to answer the wrap-up questions, possibly because so many people who were not typically part of the Storytelling Circle were present. I let go of wanting to 
gain research results from that evening's discussion and it was a really nice party. At the same time, I left not knowing whether I was saying goodbye or see you next time.

I drafted a research report based on my field notes that described the process, but I could not draw conclusions because the results were invisible to me as were the appropriate Indigenous analytical frameworks. An Elder explained how transformative the circle had been for women involved, but this was not something I could observe because I was not living within the community. I let go of the need for academic findings, happy that the unquantifiable participatory outcomes had been deemed positive. However, this process of reflection has helped me to decide to speak to them again to see if we can finish that report together, if it may be useful to them.

Was the project decolonizing research? Of course I want to say yes. I followed the lead of the women in the centre and did not attempt to establish colonial, scholarly, or institutional forms of authority. But the proposition that decolonization is not a metaphor calls into question my desire to label the project decolonizing; certainly, it did not directly restore the land to Indigenous peoples. Indeed it seems difficult to imagine a future in which this might happen. Can decolonizing research encourage settler governments to abandon the colonial project of governing over Indigenous peoples, or resolving treaties, or unceded land claims in a good way? It seems unlikely that a micro research project can have macro impacts such as that. To say yes, the question needs to be tempered. Can critical decolonization research have positive impacts for Indigenous peoples and develop better conditions within grassroots communities, which may one day lead toward repatriation of land or dismantling of the colonial university and nation-state structures? We had a glimpse of that when the Storytelling Circle assumed a dominant place within the university's R\&I Week and in its material institution. But long-term results are impossible to know."

\section{Towards a Tentative Contribution}

As we conclude these dialogues, we are in the midst of a global pandemic, which is hitting Indigenous groups hard. The Dean of Law at Lakehead University, Dr. Angelique Eaglewoman, member of Sisseton-Wahpeton Dakota Oyate, resigned levelling accusations of institutional anti-Indigenous racism. Māori scholar, Linda 
Tuhiwai Smith, whose important work we have cited here, did not have her contract renewed at the University of Waikato in New Zealand, retribution for speaking out against systemic anti-Māori racism. Indigenous scholars continue to be marginalised in or forced out of colonial universities that simultaneously deny and assert their colonial power by dismissing those who call attention to it in an attempt to hold them accountable.

This context emphasizes the urgency of decolonizing research. Therefore, we map out practices gleaned from our narratives regarding potential ways to move past settler fragility toward effective decolonizing research.

\subsection{Anti-Appropriation Research Practices}

As settlers, overcoming settler fragility means deep learning of Indigenous cultural knowledges through appreciation without appropriation. This may necessitate working with a mentor, but, also, respecting Indigenous peoples' time, energy, and expertise, settlers must take responsibility to learn from published sources. Settlers may enter into research spaces when invited, participating in research where the Indigenous community plays a leading role. Settlers should assume there are Indigenous researchers in the field and offer to work with them, knowing we will not be welcome everywhere, and overcoming fragility at exclusion. Finally, settlers should reference Indigenous scholars, and ask research participants if and how they would like to be cited.

\subsection{Unsettling Research Practices}

Unsettling research, settlers move past settler fragility to remain unsettled, engage in uncomfortable conversations; avoid defensiveness; listen, reflect, and revisit with questions. Settlers may share stories across cultural differences, but without introducing problematic cultural equivalencies or taking up space. Settlers are visitors in Indigenous communities; we may sometimes step into the circle to speak, but we must always step back out again. Settlers need to question how research can serve Indigenous communities, and resist the desire to be comfortable in unsettling moments when we are told it does not. To ensure Indigenous partners benefit from research, check in with 
them and pivot based on feedback. Unsettling research partnerships and questions should neither prioritize benefits to settlers nor secure settler futures.

\subsection{Reconciling Research Practices}

In reconciling research, settlers follow Indigenous guidelines and protocols. Research requires full prior and informed consent. The OCAP® principles provide for ownership, consent, access, and possession of data and outcomes. Kirkness and Barnhardt's (1991) 4Rs advocate respect, relevance, reciprocity, and responsibility. Settlers disclose ways in which we benefit from research, sharing benefits such as co-authorship, grant funds, book royalties, speaking opportunities, awards etc. with Indigenous partners. Settlers speak out in support of unjustly treated Indigenous students and scholars, working to dismantle systemic anti-Indigenous racism, prioritizing care for Indigenous communities over a desire to fulfill colonial university research metrics. Settlers also work beyond reconciliation towards decolonization.

\subsection{Decolonizing Research Practices}

Decolonizing research practices must dismantle the colonization of land, epistemologies, and peoples. Settlers avoid using decolonization as a metaphor including related innocence claims, such as settler nativism, adoption fantasies, colonial equivocation, decolonizing minds, a(s)t(e)risk peoples, and re-occupation (TUCK \& YANG, 2012). Instead, settler researchers can decenter settlers by recentering Indigenous cultures, epistemologies, and research leadership, aligning with Indigenous calls for decolonization. Settlers accept the incommensurability of settler colonial university research with the return of Indigenous land, and resurgence of self-determination and epistemologies through decolonization. Settlers may need to step unsettled into a future that does not secure settler power, but destabilizes it with the objective of securing political and territorial decolonization for Indigenous futurity.

\section{Conclusion}


We have shared many questions - some not ours to answer - acknowledging the limits of our knowledge and attempting to destabilize colonialism in our writing. We have employed dialogic autoethnography to reflect on and confront our own unknowing. Future research might include dialogues among settler researchers, Indigenous researchers and/or Indigenous research partners to deepen reflections. Thus, we propose these closing words not as a conclusion but as a contribution toward research practice dialogues that must, of necessity, exceed the bounds of this paper.

\section{References}

ABSOLON, K; WILLET, C. Putting Ourselves Forward: Location in Aboriginal Research. In: BROWN, L \& STREGA, S. (ed.). Research as Resistance. Toronto: Canadian Scholars, 2005. 303p. p. 97-126.

AHMED, S. Declarations of Whiteness: The non-performativity of anti-racism. Borderlands, v. 3, n. 2. 2004.

ANTOINE, A. ; MASON, R. ; MASON, R. et al. Pulling Together: A Guide for Curriculum Developers, 2018. Available at:

https://opentextbc.ca/indigenizationcurriculumdevelopers/. Accessed on: Aug. 192020.

ARCHIBALD, J. Creating an Indigenous Intellectual Movement at Canadian Universities. In: VALASKAKIS, G. G.; STOUT, M. D.; \& GUIMOND, E. (ed.).

Restoring the Balance: First Nations Women, Community, and Culture. Winnipeg: University of Manitoba Press, 2008. 384p. p. 125-148.

AVATAR. Directed by James Cameron. United States of America: Twentieth Century Fox, Dune Entertainment, Lightstorm Entertainment, 2009. (162 min), son., colour. Fiction.

BATTISTE, M. Micmac literacy and cognitive assimilation. In: BARMAN, J.; HÉBERT, Y.; MCCASKILL, D. (ed.). Indian Education in Canada, V1: The Legacy. Vancouver: UBC Press, 1986. 180p. p. 23-45.

BILGE, S. Intersectionality Undone: Saving Intersectionality from Feminist Intersectionality Studies. Du Bois Review, v. 10, n. 2, p. 405-424. 2014.

BRANT CASTELLANO, M. Ethics of Aboriginal Research. Journal of Aboriginal Health, v. 1, n. 1, p. 98-114. 2004.

BRE. Hard Livin': Bare Life, Autoethnography, and the Homeless Body. In: 
SHUKAITIS, S.; GRAEBER, D. (ed.). Constituent Imagination. Oakland: AK Press, 2007. 329p. p. 223-241

BUTZ, D.; BESIO, K. Autoethnography. Geography Compass, v. 3, n. 5, p. 1660-1674. 2009.

CHASE, S. Chapter 25: Narrative inquiry. In: DENZIN, N.; LINCOLN, Y. (ed.). The Sage handbook of qualitative research. 4. ed. Los Angeles: Sage Publications, 2011. 766p. p. 421-434.

CHRISJOHN, R.; WASACASE, T. Half-truths and whole lies: Rhetoric in the "apology" and the truth and reconciliation commission. In: YOUNGING, G.; DEWAR, J.; DEGAGNÉ, M. (ed.). Response, responsibility, and renewal: Canada's truth and reconciliation journey. Ottawa: Aboriginal Healing, 2009. 422p.

CLARK, N. Red intersectionality and violence-informed witnessing praxis with Indigenous girls. Girlhood Studies, v. 9, n. 2, p. 46-64. 2016.

CONNELLY, M.; CLANDININ, J. Stories of experience and narrative inquiry. Educational Researcher, v. 19, n. 5, p. 577-590. 1990.

COTERA, M. Women of Color, Tenure, and the Neoliberal University. In: NOCELLA, A. J.; BEST, S.; MCLAREN, P. (ed.). Academic Repression. Oakland: AK Press, 2010. 590p. p. 328-336.

DANCES WITH WOLVES. Directed by Kevin Costner. United States of America and United Kingdom: Tig Productions (presents), Majestic Films International, and Allied Filmmakers, 1990. (181 min), son., colour. Fiction.

DAVIS, L. Risky stories: Speaking and writing in colonial spaces. Native Studies Review, v. 15, n. 1, p. 1-20. 2004.

DECOSTA, R.; CLARK, T. Exploring non-Aboriginal attitudes towards reconciliation in Canada: The beginnings of targeted focus group research. In: MATHUR, A.; DEWAR, J.; DEGAGNE, M. (ed.). Cultivating Canada: Reconciliation through the Lens of Cultural Diversity. Ottawa: Aboriginal Healing, 2011. 463p. p. 327-339.

DENZIN, N.; LINCOLN, Y. Introduction: Critical Methodologies and Indigenous inquiry. In: DENZIN, N.; LINCOLN, Y.; SMITH, L. T. (ed.). Handbook of critical and Indigenous methodologies. Thousand Oaks: Sage Publications, 2008. 624p. p. $1-20$.

DHAMOON, R. A Feminist Approach to Decolonizing Anti-Racism: Rethinking Transnationalism, Intersectionality, and Settler Colonialism. Feral Feminisms, v. 4. p. 20-37. 2015. 
DE SOUZA SANTOS, B. Epistemologies of the South: Justice Against Epistemicide. New York: Routledge, 2014. 284p.

DIANGELO, R. White Fragility: Why It's So Hard for White People to Talk About Racism. Boston: Beacon, 2018. 192p.

ERMINE, W. The ethical space of engagement. Indigenous Law Journal, v. 6, n. 1, p. 193-203. 2007.

FELLOWS, M. L.; RAZACK, S. The Race to Innocence: Confronting Hierarchical Relations Among Women. Journal of Gender, Race \& Justice, v. 1, p. 335-352. 1998. FIRST NATIONS INFORMATION GOVERNANCE CENTRE. The First Nations Principles of OCAP, 1998. Available at: https://nigc.ca/ocap. Accessed on: Apr. 16 2020.

FORTIER, C. Unsettling Methodologies/Decolonizing Movements. Journal of Indigenous Social Development, v. 6, n. 1, p. 20-36. 2017.

GARBA, T.; SORENTINO, S. M. Slavery is a Metaphor: A Critical Commentary on Eve Tuck and K. Wayne Yang's "Decolonization is Not a Metaphor." Antipode, v. 52, n. 3, p. 764-782. 2020.

GILIO-WHITAKER, D. Unpacking the Invisible Knapsack of Settler Privilege. Beacon Broadside, 2018a. Available at:

https://www.beaconbroadside.com/broadside/2018/11/unpacking-the-invisible-knapsack -of-settler-privilege.html. Accessed on: June 12020.

Settler Fragility: Why Settler Privilege is So Hard to Talk About. Beacon Broadside, 2018b. Available at: https://www.beaconbroadside.com/broadside/2018/11/settler-fragility-why-settler-privil ege-is-so-hard-to-talk-about.html. Accessed on: June 12020

HAIG-BROWN, C. Indigenous Thought, Appropriation, and Non-Aboriginal People. Canadian Journal of Education, v. 33, n. 4, p. 925-950. 2010.

HELD, M. Decolonizing research paradigms in the context of settler colonialism. International Journal of Qualitative Methods, v. 18, n. 1, p. 1-16. 2019.

HENRY, F. et al. The Equity Myth: Racialization and Indigeneity at Canadian Universities. Vancouver: UBC Press, 2017. 392p.

HOUSTON, J. Indigenous Autoethnography: Formulating Our Knowledge, Our Way. The Australian Journal of Indigenous Education, v. 36, n. 1, p. 45-50. 2007. 
JEPPESEN, S. Critical Reflections on Horizontal Media Activism Research Practices. In: JEPPESEN, S; SARTORETTO, P (Eds.). Media Activist Research Ethics. London: Palgrave, 2020. 277p. p. 27-50.

JUSTICE, D. H. Settlers With Opinions. The Conversation, 2017. Available at: https://theconversation.com/settlers-with-opinions-83338. Accessed on: June 12020.

KIRKNESS, V.; BARNHARDT, R. First Nations and Higher Education: The Four Rs: Respect, Relevance, Reciprocity, Responsibility. The Journal of American Indian Education, v. 30, n. 3, p. 1-15. 1991.

KOVACH, M. Indigenous methodologies: Characteristics, conversations and contexts. Toronto: University of Toronto Press, 2009. 216p.

LADNER, K. Proceed with caution: Reflections on resurgence and reconciliation. In: ASCH, M.; BORROWS, J.; TULLY, J. (ed.). Resurgence and Reconciliation: Indigenous-Settler Relations and Earth Teachings. Toronto: University of Toronto Press, 2018. 384p. p. 245-264.

LOWMAN, E.; BARKER, A. Settler identity and colonialism in 21 st century Canada. Halifax: Fernwood, 2015. 158p.

MCIVOR, O. I Am My Subject: Blending Indigenous Research Methodology and Autoethnography Through Integrity-based, Spirit-based Research. Canadian Journal of Native Education, v.33, n.1, p. 137-155. 2010.

MCKENZIE-SUTTER, H. Poetry book on missing, murdered Indigenous women pulled following criticism from victim's family. The Globe and Mail, 2018. Available at: https://www.theglobeandmail.com/arts/books/article-poetry-book-on-missing-murdered -indigenous-women-pulled-following/. Accessed on: July 122018.

MILlOY, J. A National Crime: The Canadian Government and the Residential School System. Winnipeg: University of Manitoba Press, 1999. 424p.

MOSBY, I. Administering Colonial Science: Nutrition Research and Human Biomedical Experimentation in Aboriginal Communities and Residential Schools, 1942-1952. Social History, v. 46, n. 91, p. 145-172. 2013.

NATIONAL INQUIRY. Reclaiming Power and Place: The Final Report of the National Inquiry into Missing and Murdered Indigenous Women and Girls (Vol. 1a). 2019. Available at:

https://www.mmiwg-ffada.ca/wp-content/uploads/2019/06/Final_Report_Vol_1a-1.pdf. Accessed on: Apr. 152020. 
PIAPOT, N. Book about Gerald Stanley case upsets Colten Boushie's family due to lack of consultation. CBC, 2019. Available at:

https://www.cbc.ca/news/canada/saskatchewan/boushie-family-triggered-by-roach-book -1.5026486. Accessed on: Aug. 202020.

REGAN, P. Unsettling the Settler Within: Indian Residential Schools, Truth Telling, and Reconciliation in Canada. Vancouver: UBC Press, 2010. 316p.

RIESSMAN, C. Narrative methods for the human sciences. Los Angeles: Sage Publications, 2007. 251p.

ROACH, K. Canadian Justice, Indigenous Injustice: The Gerald Stanley and Colten Boushie Case. Montreal: McGill-Queen's University Press, 2019.

SHAND, P. Can copyright be reconciled with First Nations' interests in visual arts?

Protecting Knowledge: Traditional Resource Rights in the New Millennium conference, University of British Columbia, Vancouver, 2000. p. 1-26. Available at: https://web.archive.org/web/20080609172204/http://www.ubcic.bc.ca/files/PDF/shand. pdf. Accessed on: Sept, 202020.

SMITH, L. T. Decolonizing Methodologies: Research and Indigenous Peoples, 2. ed. London: Zed, 2012. 242p.

STYRES, S. Pathways for Remembering and Recognizing Indigenous Thought in Education: Philosophies of Iethi'nihsténha Ohwentsia'kékha (Land). Toronto: University of Toronto Press, Scholarly Publishing Division, 2017. 248p.

THE LAST OF THE MOHICANS. Directed by Michael Mann. United States of America: Morgan Creek Entertainment and Twentieth Century Fox, 1992. (112 min), son., colour. Fiction.

TRC. Honouring the Truth, Reconciling the Future: Summary of the Final Report of the Truth and Reconciliation Commission of Canada, 2015. Available at:

http://www.trc.ca/assets/pdf/Honouring_the_Truth_Reconciling_for_the_Future_July_2 3_2015.pdf. Accessed on: Aug. 122020.

TUCK, E.; YANG, W. Decolonization is not a metaphor. Decolonization: Indigeneity, Education \& Society, v. 1, n. 1, p. 1-40. 2012.

WATSON, K. Understanding Indigenous and non-Indigenous Perspectives of Reconciliation. 257p. PhD Dissertation, Faculty of Education, Western University, 2020 .

WEBB-CAMPBELL, S. Who Took My Sister?. Toronto: BookThug, 2018. 
WHITINUI, P. Indigenous Autoethnography: Exploring, Engaging, and Experiencing "Self" as a Native Method of Inquiry. Journal of Contemporary Ethnography, v. 43, n. 4, p. 456-487. 2014.

WILSON, S. Research is Ceremony: Indigenous research methods. Halifax: Fernwood, 2008. 144p.

WOOLFORD, A. The limits of justice: certainty, affirmative repair, and aboriginality. Journal of Human Rights, v. 3, n. 4, p. 429-444. 2004.

YURCHUK, Y.; VORONOVA, L. Challenges of Ongoing Conflict Research: Dialogic Autoethnography in Studies of Post-2014 Ukraine. In: JEPPESEN, S.; SARTORETTO, P. (ed.). Media Activist Research Ethics. London: Palgrave, 2020. 276p. p. 249-268. 